\title{
Significados locales de la empresa social. Una visión sobre hibridez de organizaciones desde el particularismo histórico ${ }^{1}$
}

\author{
Richard Pfeilstetter ${ }^{2}$ e Itzíar Gómez-Carrasco ${ }^{3}$ (e)
}

Recibido: 8 de julio de 2019 / Aceptado: 25 de septiembre de 2019 / Publicado: 18 de mayo de 2020

\begin{abstract}
Resumen. La hibridez es un concepto muy extendido para enmarcar el emprendimiento social como una combinación de negocio y bienestar social. Comparando dos empresas de inserción sociolaboral de Glasgow y Viena, este artículo explora como el significado de hibridez se construye localmente en Austria y Escocia. Muchas organizaciones pueden ser definidas como "híbridas" en base a análisis formales, sincrónicos y aislados. Por el contrario, un análisis en profundidad a menudo confirma que las organizaciones supuestamente híbridas suelen tener un desequilibrio importante entre sus objetivos sociales y económicos. Esta discusión en torno a la "falsa" o "verdadera" hibridez de las organizaciones concibe de manera inadecuada el valor social y económico en términos universales y absolutos, mientras que nosotros defendemos que su significado se negocia localmente. Por lo tanto, el punto intermedio entre altruismo y beneficio varía en función de una serie de instituciones, mercados, actores y regímenes de bienestar específicos e históricamente evolucionados.
\end{abstract}

Palabras clave: Organizaciones híbridas; Empresa social; Escocia; Austria; Emprendimiento social.

Claves Econlit: A13; B55; D69; L31.

[en] Local meanings of social enterprise. A historical-particularist view on hybridity of organizations

\begin{abstract}
Hybridity is a widely used concept for framing social enterprising as the combination of business and social welfare. By comparing two work integration enterprises from Glasgow and Vienna, this article sheds light on the locally constituted meaning of hybridity in Scotland and Austria. Many organizations comfortably fit into a formal, synchronic and isolated interpretation of hybridity, while in-depth-analysis often shows that organizations have a strong unbalance between their social and economic rationale. This discussion over real versus false hybridity of organizations inaccurately places notions of social and economic value in absolute terms, whereas we argue that their meaning is negotiated locally. The middle ground between profit and altruism is shifting due to particular, historically evolved institutions, markets, actors and welfare regimes.
\end{abstract}

Keywords: Hybrid organizations; Social enterprises; Scotland; Austria; Social entrepreneurship.

Summary. 1. Introduction. 2. Hybridity and social enterprises. 3. Methodology. 4. ARTE: between for-profit and welfare-state corporations. 5. Coop: hybridity over time. 6. Conclusions: contextualizing social enterprises. 7. References.

How to cite: Pfeilstetter, R.; Gómez-Carrasco, I. (2020) Local meanings of social enterprise. A historical-particularist view on hybridity of organizations. REVESCO. Revista de Estudios Cooperativos, vol. 134, e69162. https://dx.doi.org/10.5209/REVE.69162.

\section{Introduction}

Individuals currently labelled as "social entrepreneurs" and their organizations, "social enterprises", are receiving growing attention from practitioners, policy makers, academics and the media. The label social enterprise is predominantly used to describe organizations that pursue social goals by means of the market (Kerlin, 2009) although it is also being used to refer to an increasingly wide range of initiatives. The structural background of this development is the growing retreat, poor functioning, or reduction of statefinanced social welfare (Kerlin, 2010: 167). The concept of social enterprise is far from new, but in recent years it has taken a new turn, appealing to a vast range of people, concepts and business modalities. High-

\footnotetext{
Funding was provided by Horizon2020 Marie-Skłodowska-Curie Actions (Grant No. 688991).

Universidad de Sevilla, España

Dirección de correo electrónico: rgp@us.es

3 Universidad de Sevilla, España

Dirección de correo electrónico: igcarrasco@us.es.
} 
profile experiences such as the Grameen Bank in Bangladesh and its founder Muhammad Yunus, who won the 2006 Nobel Peace Prize for providing banking services the poor, have increased the interest and understanding of the general public on the core ideology of social enterprising, namely that profit and charity can go hand in hand.

From the outset, the danger of its growing popularity has been for too many "non-entrepreneurial efforts" to be included in the definition, losing the essence and usefulness of the concept as a result (Martin and Osberg, 2007: 30). Furthermore, the concept of social enterprise is contested almost by definition, since its meaning varies according to political, historical, geographical or cultural factors (Teasdale, Lyon and Baldock, 2013). In recent years, Western welfare states have undergone substantial transformations, with the State showing what has been described as "increasing openness toward the market as a social service deliverer" (Hustinx and De Waele, 2015: 1668). In the context of Europe, the recent crisis brought to the forefront the limitations and unexpected frailty of what was deemed to be a robust welfare system that was firmly embedded in the European political culture, and ultimately caused a crisis of the welfare systems in terms of budget, efficiency and legitimacy (Defourny, 2010).

Against this backdrop, social entrepreneurship began to attract ever-growing attention as a phenomenon that could provide alternatives to existing solutions, products and services, respond to an existing gap, defy an "unsatisfactory equilibrium" (Martin and Osberg, 2010) or emerge in response to a pressing social need. At present, the term social entrepreneurship is also being interchangeably used in relation to certain forms of traditional social services or product provision. These apparent contradictions and definition problems inherent in the social enterprise concept are frequently addressed in the academic literature through the term "hybridity".

We will discuss part of this literature on social enterprises as hybrid organizations in the following section, by distinguishing between approaches that place social value, economic sustainability or the controversy over their compatibility in absolute terms, versus those approaches that place the meaning of hybridity in each local context. We will then present the methodological setting of our research, grounded in a collaborative European commission-funded project, where we gained first-hand insights from third sector practitioners in different European countries through mutual long-term visits. Drawing from this research, the fourth and fifth section are dedicated to presenting two work integration social enterprises, namely ARTE (Vienna) and Coop (Scotland). We will discuss different empirical evidence for each social enterprise supporting arguments previously identified in the literature. In the conclusions, we will compare both cases in light of on-going discussion over "real versus fake" hybridity and seek to make an argument for the underrepresented historical-particularistic viewpoint in this debate.

\section{Hybridity and social enterprises}

Literature on hybridity in human organization has a long history. In the 1920s, one of the founding fathers of modern social anthropology, Marcel Mauss, described the gift as a cross-cultural human trait that combined utilitarian self-interest and free benefits. It is mandatory to give, receive and return items of value in all societies (Mauss, 1925). In the 1990s, debates over networks as a new organizational logic that mixed the workings of the hierarchy and of the market, emerged (Powell, 1990). It is only more recently that hybridity has been closely related to the debate on social enterprises. Here, the modern mind-set of problem-solving, calculation and reasoning are thought to combine with traditional values of charity and moral responsibility towards the community in new ways (Dees, 2012: 323-324, 326).

Within management and organization studies, social enterprises are often held as the ideal type of hybrid organization (Battilana and Lee, 2014). These organizations combine two different institutional logics because hybrids are "structures and practices that allow the coexistence of values and artefacts from two or more categories" (Doherty, Haugh and Lyon, 2014: 418). Hybrid organizations combine two logics simultaneously in their mission, namely their financial resource acquisition and their human resources profile (Doherty, Haugh and Lyon, 2014). Some distinguish between integrated hybrid organizations where beneficiaries are also customers, and differentiated hybrids, that organizationally separate business performance and social mission (Ebrahim, Battilana and Mair, 2014: 83). In addition to these two models (disadvantaged groups as clients and corporate social responsibility), Jäger and Schröer (2014) also include enterprising non-profits and third sector organizations, that are neither private nor public, into the population of hybrid organizations. Others, like Gidron, distinguish between hybridity of form (profit distribution and governance) and of substance, with everyday practices trying to reconcile this twofold mission (2017). Battilana and Lee hold that hybridity in social enterprise means combining two logics at the core of the organization, as opposed to organizations with a social mission at their periphery, for example a social engagement from for-profit corporations (2014).

While some celebrate the opportunities of hybrid organizations because they are "civilizing the economy" (Grassl, 2012: 109-10), others are concerned with "mission drift" where good economic performance 
conceals poor social performance or social activities are merely legitimizing business as usual (Ebrahim, Battilana and Mair, 2014: 88). Generally speaking, organization scholars attribute both the danger of disorder and the potential of creativity to social enterprise (Battilana and Lee 2014: 398). This short review shows that in the literature on social enterprises, existing "hybridity" is often first taken for granted in order to examine what type of organizations are involved, what areas within organizations are affected and what specific outcomes of hybridity can be suspected. This line of inquiry provides a strong channel for discussing the possibility, conflicts and potentials of organizations that simultaneously combine two different purposes.

Nevertheless, the above-mentioned focus excludes some important questions from the debate, namely the specific historical, political or cultural contexts that shape social enterprises (Teasdale, 2011). Literature on hybridity in organizations often creates the impression that it is a universal feature of human organization, even when it foremost discusses western or international flagship social enterprise projects, such as the Grameen Bank mentioned in the introduction. This line of research tends to limit itself to an isolated and synchronic analysis of social enterprises (Dey and Teasdale, 2016: 490). In addition, social enterprises (and their promoters) often define themselves as "combining the best of both worlds", which leads to a problematic overlap between the empirical reality under scrutiny (social enterprises) and the theoretical devices thought up for their examination (hybrid organizing). At this point, academic categories start to lack the necessary distance from self-descriptions of institutions. Thus, many researchers have uncritically taken for granted policy definitions, newness and growth (read existence) of social enterprises (Kerlin 2010: 164; Teasdale, Lyon and Baldock, 2013). Concerned with these problems, the second thread in the literature therefore stresses the social environment that defines organizations.

In this line of enquiry, recent evidence shows that the coexistence of doing good and business is often not achieved in practice. Hustinx and De Waele have reported on a representative third sector organization in Belgium that acted as a social enterprise to fit the demands of the funding environment (2015: 1687). A social grocery was created as an alternative to food aid, in order to fit with the social enterprise ideology. While employees maintained a critical attitude towards the marketization of welfare, in everyday practice "participants were 'commodified' by subordinating their needs to the service and business logic of the grocery" (Hustinx and De Waele, 2015: 1686). In the UK, Teasdale, Lyon and Baldock found that many third-sector organizations did not engage in market activity but nevertheless described themselves as social enterprises (2013). On the contrary, caution is also necessary when considering third sector organizations that trade, as a report from Dey and Teasdale demonstrates (2016). The authors offer an in-depth study of an English flagship social enterprise that apparently fitted into the dominant policy definition for social enterprise by offering work integration through a construction, hotel and gardening business. The organization tactically adopted a dominant policy discourse, acting "as if" it was a social enterprise (without believing in the compatibility of profit and charity) in order to enable access to public funding for the provision of social services (Dey and Teasdale, 2016: 498-499). Ironically, this apparent pro-enterprise "impression management" was merely hiding and therefore supporting major state dependence (Dey and Teasdale, 2016: 501; Teasdale 2010). In Spain, José Luis Molina and his team recently accomplished a large scale analysis of the nascent social enterprise sector in Catalonia, finding that the sector was largely sponsored by the state and by the private banking sector that had substituted the social projects implemented by cooperative banks that widely disappeared as a result of the financial crisis (Molina et al., 2017). In Catalonia, clients of social enterprises were mainly middleclass as opposed to part of more vulnerable groups, while simultaneously, social enterprise creation was mainly a self-employment strategy by those who were already well-off (Valenzuela-García et al., 2015). This observation was also made by Steiner and Teasdale for social enterprises in London (2016). Taken together, this evidence from western Europe indicates that the social enterprise label often masquerades either state-funded welfare or market-driven business, marking what has been described as "a new era of welfare hybridity" (Billis, 2010).

Up to this point we have shown two differential treatments of social enterprise as hybrids in research. On the one hand, the more theoretical, synchronic management focus on social enterprise as ideal-typical hybrids. On the other hand, a more empirical-sociological focus on social enterprises, that investigates a new policy endorsing hybridity and enterprising within a third sector dependent on public-private funding. Despite those differences, what is common to both treatments of hybridity in social enterprise is that they are setting "doing good" and "doing business" in absolute terms. It is not only the specific meaning of the term "social" in social enterprise that is often concealed (Teasdale, Lyon and Baldock, 2013: 116) but even what is held as social need or economic self-sustainability of third sector organizations in different societies. Social problems are constructed socially, which means that they are "definitional activities of people around conditions and conduct they find troublesome" (Schneider, 1985: 209). Therefore, much variability is to be suspected over what is judged collectively as a social need and what kind of services are held to be "merely commercial". Looking at social enterprises from this comparative angle has received much less attention in the literature (Kerlin, 2010: 164-165). Therefore, what we would like to suggest in this paper is the idea that research on hybridity in organizations could benefit from introducing more local meanings of hybridity to the discussion. If hybrids "deviate from socially legitimate templates for organizing" (Battilana and Lee, 2014: 
398, also Gidron, 2017: 8) then it is fair to expect a wide variability of legitimate organizational types in different societies. It is an oversimplification to assume that the public, private and third sector are genuine, separate, legitimate, and equally distributed organizational templates everywhere, anytime.

The hybrid status of the micro-finance bank in Bangladesh, the work integration enterprise in England or the social grocery in Belgium cannot be attributed indistinctively, regardless of whether these organizations fail or succeed in accommodating a social mission with working profitably according to local standards. What standards are applied to these organizations in poor or rich, western or non-western, liberal or sociodemocratic (welfare) states? For example, should the self-employment strategy by the middle-class in the Catalonian social enterprise sector be judged as an indicator of a failed social mission of organizations that only simulate hybridity? Or on the contrary, is self-employment in the third sector an indicator of successful hybridity in a country like Spain, with high unemployment numbers and one of the weaker welfare states within the European context? It is fair to say that employment is a pressing social need for the middle class in contemporary Spain, which is not necessarily true in the UK, Belgium or Germany. Before we set out to discuss those locally bounded meanings of hybridity in two organizations embedded in different European welfare regimes, we present the larger setting of our research and its methodological point of departure.

\section{Methodology}

Research for this paper was part of a three-year European Commission funded project that investigated the conditions for success of social enterprises. On the one hand, the project tried to fill existing gaps in the research on the socio-political and economic environment that sets the conditions for the growth of these organizations. On the other hand, the project aimed at contributing to address the dearth of first-hand knowledge and exchange between practitioners and academics in this field. To this end, staff from partner organizations involved in the project (eleven social enterprises and seventeen research institutions from seventeen countries) had the opportunity to visit partners from a different country and sector (practitioner or academic) for one or several months. In this larger research context, we were responsible for conducting research on the Spanish social enterprise sector, hosting staff from foreign partner organizations and visiting social enterprises both in Spain and abroad.

In particular, the findings of this paper draw on collaborative research with practitioners from the Scottish and Viennese social enterprise sector through observational visits, informal conversations, recorded interviews and the analysis of documents from social enterprise lobby organizations and the administration. For this paper, we have anonymized the names of the examined social enterprises and of our non-academic informants. In 2016, we concluded a two-month field research visit to Vienna (Austria). This long-term visit allowed us to repeatedly attend and observe the work integration social enterprise ARTE at two of their dependencies. There we talked to both staff and clients and we conducted in-depth interviews with the shopmanager and the founder. We have alternated our field research with work at the Competence Center for Nonprofit Organizations and Social Entrepreneurship at the Vienna University of Economics in order to deepen our understanding of the welfare context in Vienna and Austria. Our research was complemented with an analysis of the media coverage of ARTE, their self-presentation on their web and their promotional artefacts on their dependencies. We also visited competitors of ARTE from the corporate welfare sector.

The second social enterprise analysed in this article is Coop. Our analysis of this experience included a literature review of documents related to the work and history of this social enterprise and the Scottish context for social entrepreneurship, including a country report on Scotland (Roy, 2016). This was complemented with in-depth interviews with one of the founders and one of the current senior managers. A Coop manager spent a month visiting the University of Seville and this provided a suitable opportunity for the research team to exchange on social enterprises and to gain insights into Coop's experience. A set of open-ended questions was developed to guide the conversations, including a questionnaire focusing on the organization's development to date. Certain comparative aspects of the Andalusian and Scottish contexts were raised and discussed during the visit.

We have selected these two cases for our research because they share certain characteristics. Both social enterprises are active in the field of work integration and combine a twofold income strategy (public funding and trading). They both have a certain degree of autonomy from the state or the private sector: they do not distribute profits to shareholders and have a similar social mission in providing employment for vulnerable groups. While Coop is certainly a larger organization than ARTE, they are both consolidated (existed for longer than 15 years), fairly small-scale organizations (less than 80 full time employees), and embedded in the local communities they are active in (both organizations are well known to the general public in Vienna and Scotland). Our guiding research question was how similar organizations performed in different welfare regime contexts and in particular, whether the hybridity of organizations was different in each context. While Vienna is known for a longstanding, intense socio-democratic welfare policy from the city council, Scotland and the UK are fairly liberal environments for third-sector organizations compared to continental Europe. 
Comparing two similar organizations in two dissimilar welfare contexts, allowed us to test our hypothesis, namely that local organizational arrangements and life-worlds put allegedly absolute terms, such as "competition versus compassion", into perspective.

In the following two sections we present our two case studies, the work integration social enterprises Coop and ARTE. We will show how the contexts of a liberal (Scotland) and socio-democratic (Austria) welfare system set different conditions of possibility for combining conflicting institutional logics. This social context also defines the meaning and the form of the "social" or "economic" rationale. Hybridity therefore has a different appearance in the two cases, that cannot be easily reduced to a universally valid distinction of financial versus social motivation. We argue that the social enterprises we observed perform their activities in what constitute different context-specific struggles with local and national administrative arrangements. By simultaneously conforming to hegemonic public funding schemes, while also testing market income opportunities and challenging monopolist third-sector corporations, these organizations qualify as hybrids when a more context-sensitive definition of the concept is followed.

\section{ARTE: between for-profit and welfare-state corporations}

ARTE was established in 2002 in Vienna and is an association with 13 fixed-term employees that offers work integration and training to a varying number of around 35 persons who are former drug users. These workers remain at the organization for a maximum of one year, assembling hand-made design products, such as furniture, bags, clothes and accessories, using waste as raw material. Their upper-price segment products are sold and promoted at the organization's gallery-like shop located in a creative district of the city. Formally speaking, ARTE qualifies as a hybrid organization because its market activity - selling design products - is integrated into its social mission, facilitating the (re-)entry in the labour market for former drug users. This hybridity at the heart of the organization was illustrated by the following quote from the founder, a social worker in her early fifties, when she reflected on the organization's tension between its economic and social rationale.

From a business angle I would need to employ a different group, any other long-time unemployed persons [as opposed to persons with former drug dependence]. When they are good [at their job], they leave. We have people who are sometimes only productive $50 \%$ of the time.

From a legal point of view, ARTE can also be considered a characteristic social enterprise. Five different types of "socio-integrative companies" qualify for public support in Vienna, and ARTE falls under the category of "socioeconomic company" (SÖB), which can receive funding from the public employment service but needs to generate a significant amount of turnover in order to ensure its self-sustainability (DSEWien, 2014: 4). Another criterion that is often used to define social enterprises is the innovative dimension, which is also present in ARTE, since it adds an ecological angle to its social mission. In addition, employees have the possibility of engaging in creative work assembling hand-made products. Thus, ARTE is challenging a widespread tendency in work integration social enterprises that offers typically unskilled, simple, and repetitive work. Taken together, ARTE seems a prototype of a hybrid organization.

However, a closer look at ARTE reveals a different picture. The overwhelming source of income for ARTE is public funding. In 2015, this represented over $70 \%$ of its total income, while market revenues only reached 21\%. This means that ARTE must adapt its employment schemes to the demands of the Austrian Public Employment Service and the Department for Drug Addictions of the city of Vienna, its two main sponsors. In fact, ARTE started as a project supported by the European Union. ARTE's strong dependency on public resources and its need to constantly persuade the administration to secure the next funding, threatens its independence and can be read between the lines in the following statement from the founder.

I am the one who has the networks and looks for the money but without everyone's help ARTE wouldn't exist today.

On the other hand, the founder and manager has been an employee of a large private clinic ever since ARTE's foundation. Hence, it would seem that a strong engagement with ARTE was only feasible against the backdrop of having a securely paid job elsewhere. One could even talk of "intrapreneurship" here (creating a new organization within an existing one), because at the beginning, ARTE was supported by large amounts of funding provided by this clinic and was in fact created by one of its employees, which again raises questions of whether the organization is truly independent, a major defining feature within the discourse on social enterprises.

While both ways of approaching the case of ARTE (i.e. whether as a "true or false" hybrid), give valuable insights into the possibility of enterprising in the non-profit sector, both considerations exclude specific local perceptions and conditions of hybridity from the debate. In order to contribute this important third layer to the discussion, the following section will consider the workings of the Austrian welfare regime, the local 
characteristics of organizations working in similar fields as ARTE and the conditions of the market for recycled, socially-responsible design products in the city of Vienna.

The Austrian welfare state, similar to the German, is a system that benefits large public or publicly funded welfare corporations (Esping-Andersen, 2001: 111-114). Public spending, particularly in Vienna, a city governed by the social democrats (SPÖ) for decades, is comparatively high in a context of widespread prosperity. Therefore, maybe it comes as no surprise that many "social enterprises" were providing recycled and socially responsible goods at the time of our field work. Apart from ARTE, the local administration, responsible for waste management in the city of Vienna, promoted a fashionable shop selling items that citizens had thrown away at the communal recycling centres but were still in usable condition and/or had been repaired. Also "Caritas", one of the largest providers of social services in many continental welfare regimes with a catholic tradition, ran a shop selling accessories made from recycled materials. Needless to say that ordinary businesses in Vienna also trade, under the label "environmentally and socially responsible", products made from waste materials.

With this context in mind, consider the following example. During our fieldwork we came across quite a particular product: bags made of old truck canvas. One might think that this is a rare niche commodity. Nevertheless, exactly the same item was manufactured and sold by two different organizations in shops situated about two kilometres away from each other in the centre of Vienna. Apart from ARTE, one of the organizations selling this product was "Caritas", who sold the bags as part of a work integration project for young people with no schooling and the other was "Freitag", an international corporation that had made these kinds of bags popular in the 1990s. These two competitors were part of a microcosm for recycled design-products in the wealthy city centre of Vienna and we found that insiders of this social space defined their corporate identity in comparison to other actors. On the one hand, Freitag, a for-profit organization with 150 employees and an estimated turnover of around 30 million Swiss francs in 2015, lacked the essential social commitment of ARTE and Caritas. Nevertheless, if we hold the ecological dimension as an important variable for social value creation in this example, the founders of Freitag contributed indirectly with their invention of a sustainable product that both social businesses were imitating and exploiting for social purposes. On the other hand, Caritas Austria was active in virtually all social service branches in and outside the country. In 2015, it had a budget of close to 800 million euros and around $69 \%$ of its budget was publicly funded, 16\% came from commercial revenues or fees and 11\% from donations (Caritas Österreich, 2016: 15, 18). With 14.871 employees, Caritas was one of the largest organizations in Austria and the key provider of social assistance on behalf of the state.

Within a continental welfare system, the subsidiarity of the state privileges large, historically consolidated public corporations with close ties to the administration. While for Caritas the commercial revenue from recycled products at their Viennese workshop for young people represented an insignificant activity within the organization, for ARTE the canvas bags had been the main flag-ship product sold from the beginning. In turn, Freitag assembled these items industrially and without paying major attention to social constraints of its employees. In this social context, as our example of the bags tries to illustrate, ARTE is confronted with superior multinational corporations as competitors, both in the private market of sustainable life-style products and in the state-funded field of work integration. From this local perspective, within a welfare regime where the market has only a residual function in the provision of social services, ARTE is a hybrid organization compared to its immediate organizational surroundings. It is relatively far-off the market and the state, in comparison with Freitag and Caritas. Bringing this local knowledge to bear upon the "global" notions of market and charity, contributes to a more nuanced theory of hybrid organizing, as our next example also illustrates.

\section{Coop: hybridity over time}

Coop has the status of a limited company with charitable status under Scottish law and can thus be considered a social enterprise from a legal point of view. It was founded in the late 1980s at a time marked by a sharp rise in unemployment due to the collapse of the shipyards, a key industry in Scotland. In response to the crisis, the Government made funding available to support the affected local community and create new employment opportunities. Coop was founded by a group of unemployed men and women from this sector with the objective of accessing the public funding available to support employment generation. At present, Coop is still led by two of the individuals who were initially hired to develop the first of these programmes and who have been at the heart of the organization for over thirty years.

Since its creation, Coop has established good relations with the community and the local authorities. These local ties have been highlighted by one of the Coop managers as a crucial factor for the organization's performance as a social enterprise and for the pursuit of its social objectives. The staff currently stands at approximately 75 full-time and 35 part-time positions. Almost all employees live locally and are connected to other social enterprise and similar initiatives in the area. As one of the managers noted, "we don't do 
things to people, the organization has grown in the community". This embeddedness in the local community constitutes a defining feature of many SE.

Coop can also be considered a hybrid, since it is an organization that clearly carries out a market activity, namely the implementation of employment integration programmes, for social benefit. As one of the managers noted, "the social vision is not explicitly part of Coop's mission but is implicit in everything we do". For over 30 years, Coop has been creating employment while simultaneously embarking on new projects and managing to innovate by incorporating new areas of work, for instance in the realm of cultural heritage (such as investing in the restoration of buildings). Over the years, Coop has engaged in a wide range of activities and diversified its fields of action while the tendency has been for organizations to specialise and become the only experts in a certain field. In this respect, a Coop manager said that "their specialisation is not to have one".

Nevertheless, there are several indicators that allow a questioning of Coop's position as a hybrid organization. Coop's evolution from functioning as an "end-point" social enterprise (i.e. creating and providing employment opportunities directly), to focusing on implementing employability programmes, has created a certain imbalance between its social goals and the need to secure resources through competitive methods. This suggests that Coop might have suffered a "mission drift" over time, thereby undermining its initial hybrid organizational structure. The above-mentioned imbalance has affected the organization's independence at times, which is one of the defining features of social enterprise. Similar to other social enterprises, Coop has had to fight to avoid what the founder described as a situation where "the money that comes in determines how you operate as opposed to your mission". However, at the same time, Coop has taken difficult decisions that challenged Scotland's liberal welfare regime by refusing to take part in certain funding opportunities with "strings attached" that compromised Coop's mission and raison d'être. Coop decided not to accept funding on these terms and lost staff members as a result. In a changing landscape, Coop understood that, as put by one of the managers

the practical application of continuing to be morally in line was the loss of jobs of our colleagues. Opportunities were lost but Coop's philosophy was protected.

By acknowledging this contradiction between welfare objectives and commercial activity, different to the political discourse that strategically neglects this opposition all together, the Coop founders recognize the difficulty of hybrid organizing. For them it is more an issue of

living with this tension and understanding our mission. Our mission is to create jobs for local people. Full stop. After that, we need to do whatever we need to do to achieve that: contracts, fundraising...

Secondly, there is the fact that the criteria used to determine the population targeted by the employment programmes implemented by Coop depend on how they are defined in the different contracts. Socioeconomic and geographic criteria are also considered for certain programmes, namely those using Scottish Index of Deprivation indicators to provide services to the poorest $15 \%$ of the Scottish population. This might lead us to think of Coop as a donor-driven not a client-driven-organization. In fact, Coop largely depends on the availability of public funds, which constitute its main source of income and funding. Competitive tenders are part of its operations and the organization sometimes runs the risk of "having lots of eggs in one basket", since a single contract can represent $80 \%$ of Coop's income at a given moment. Coop managers stressed the importance of "being around at the right time" as well as their ability to make a good case via à vis the local authorities by "analysing and presenting clearly what will be lost without our action". The complementarity of Coop's actions with existing policies has thus been key for their development and situates the organization closer to the administration than to the market.

Hence, when Coop's experience is analysed, the above-mentioned factors suggest that it is not a hybrid, since it operates with a certain imbalance between its social mission and its market-related delivery activities as a result of its dependence on public funding and its close relationship with local authorities. Coop was always grant-funded until 15 years ago when the welfare sector began to evolve, and local authorities increasingly focused on contracts. Nevertheless, taking the recent shifts of the policy environment in Scotland into account and adding some information on the internal workings of Coop, allows us to assess its organizational typology from a different angle. At the time of its creation, Coop had a wide range of different components that constituted enterprises within the organization in their own right, including a printing house, various workshops and a nursery. When the opportunity to implement employability programmes emerged, Coop switched its focus from efforts to create local community enterprises that could provide jobs directly to a focus on implementing employability programmes and delivering related services. Therefore, such a temporal or diachronic assessment of the organization could favour an argument that suggests that Coop is a hybrid over time.

In this respect, a key turning point in the organization came in 1997, when Tony Blair won power and the Labour Government introduced more funding for new programmes and projects as part of its social policy. 
As a direct result of these opportunities, the organization grew and the number of staff multiplied. The "devolution of powers" to Scotland also happened at the same time. This process of decentralisation within the UK that devolved decisions over social issues such as training, housing, health, education or social work to the Scottish government also opened new opportunities indirectly for Coop. Local authorities argued that this type of devolved actions contracted and implemented by third sector organizations would make them more sustainable. In Scotland, the contracting system operates in favour of social enterprises at the Local Council level and grants and loans exist for social enterprise to bid for public buildings. Particularly, the Community Empowerment Act has been key for organizations like Coop, since it allows for more organizations to join Development Trusts as an important element of their work. This act has allowed community groups to bid for public buildings and grants or loans are available to purchase them. Beyond a physical base, this element has also provided a financial base for social enterprises that has allowed greater development, since having assets facilitates access to credit.

This illustrates how the changing nature of the regional welfare regime has shaped Coop's evolution and how the local context has redefined what hybridity means for the Scottish context. In this particular setting, Coop has sometimes engaged in projects that were not fully aligned with its priorities in order to continue functioning. Therefore, Coop has developed and has to be understood within this changing legal, institutional and policy environment setting the conditions of possibility for third sector organizations to earn income through trading or tenders. Coop has evolved in a period with grants and government support available and has successfully tapped into many different sources of funding. This flexibility over time to the locally specific arrangements of public-private cooperation can be viewed as integral to the hybridity of organizations. This is the capacity to adapt to changing contexts and seize emerging opportunities. As one of the founders noted in reference to their type of work along these differences, "I take away the boxes... we can find one later if we need one".

But not only an analysis of the local conditions, but also the local perceptions of social enterprising undermine an oversimplified picture of organizations as either pure or failed hybrids. Coop has apparently adopted practices associated with for profit enterprises, such as hiring consultants or establishing a Management Board. However, in the case of Coop, both the consultant and Board of Management members are people from the community, including members of similar organizations, selected for their skills and experience. This suggests that the value of understanding who is hired and why was more important than the expectation of cost efficiency or competitive advantages. Especially a superficial focus on the mere job titles of the Coop "managers" might be misleading for our analysis here. Let us think for a moment in the increase of fancy professional designations and job profiles in the corporate world, such as the "experience ambassador" or "chief happiness officer". These names often conceal traditional designations, such as director of marketing or personnel manager, and do not necessarily speak of flat hierarchies or democratic organization within a company. In turn the label "board of management" at Coop could be misinterpreted as an indicator for "market-drift" if we do not take into account who was hired, why and how. In this sense, the intentions and perceptions of organizations are also a key dimension for understanding hybridity in social enterprises. At the same time, this forces us to take the people and organizations we study seriously, including their own criteria and local situation, not only the concepts we place upon them.

\section{Conclusions: contextualizing social enterprises}

In this paper we have discussed academic literature addressing social enterprises as hybrid organizations. We argued that many authors either overestimate the formal indicators of hybridity in organizations or to the contrary focus on empirical evidence that supports that the "hybrid social enterprise" is a flawed concept not in line with on-the-ground practices. Some authors expand this argument by saying that social enterprising is just another attempt to extend the capitalist discipline towards society (Presta, 2007: 179). We have explored these two ways of looking at social enterprises when presenting the two organizations of this paper.

On the one hand we have discussed how both ARTE and Coop display formal and legal features associated with hybrid organizations. They are legally constituted as organizations pursuing a social goal relying simultaneously on market activity and public funding to fulfil their mission. On the other hand, despite their formal independence, both organizations are close to being "a creature of public funding" (Peattie and Morley, 2008: 43 quoted in Teasdale, 2011: 106). For instance, Coop switched its focus over the years from previous efforts to create local community enterprises that could provide jobs directly, to a focus on the direct implementation of employability programmes and the delivery of related services. This dependence, as one of the Coop managers pointed out, sometimes "narrows down the delivery to what you do without the creative opportunities of doing different things at the same time". In the case of ARTE, we have an organization that is displaying high-end design products in a flagship store in the Austrian capital's city-centre, with a strong presence in the local media through the sale, for instance, of canvas bags, as discussed in the previous section. This display of ARTE as an innovative product-selling enterprise contrasts 
largely with the structural dependence on the money from the public employment service and the city council.

Nevertheless, these arguments over "false or real" hybridity in social enterprises share a common expectation for an absolute answer to this question anytime and anywhere. These universal claims on particular organizations are challenged once we admit that the meaning and form of hybridity in social enterprises is also negotiated locally. The organizations' point of view as well as the historically evolved particular institutional arrangements of the state, the market and the civil society, set the conditions for the ways in which hybridity might be perceived and enacted. This is exactly the point of departure of the project presented in the methodology section to which we have contributed. Kerlin is one of the major exponents of this underrepresented comparative thread in the literature. For her the common organizational types of social enterprise in western-Europe are associations or cooperatives with a focus on employment and with a social economy sphere that is different to the market economy (Kerlin 2010: 170). While in other regions of the world the main source of funding for social enterprises are the private sector, the civil society or international donor organizations, in Europe the main sources are the State and the European Union (Kerlin, 2010: 171).

The experiences presented in this paper fit well into this specific western European model of social enterprise. Given the absence of employment opportunities tailored to meet the needs of certain groups facing barriers to access the regular job market, Coop and ARTE stepped in to fill this gap. The fact that they are supported largely by the administration to do so is, from this comparative perspective, less an expression of failed hybridity than of the particularities of the western European welfare state. But we have put forward arguments that support an even more context-specific analysis of the hybrid character of social enterprises. In the Austrian case, we find that the social economy is mainly dominated by large, traditionally evolved welfare corporations and the market economy is increasingly crowded with corporations displaying their social and ecological responsibility, especially in prosperous places such as Vienna. The hybridity of ARTE, as exemplarily shown by its role in the market for ecological canvas bags in the city centre, can best be appreciated taking into account this place-related institutional "in-betweenness". In the Scottish case, Coop has navigated changing political contexts with three different government set-ups. The adaptability of organizations that succeed in analysing the local context and mitigating any effects on their operation are two characteristics that clearly resonate with the hybridity discourse. Therefore, the diachronic reading of organizations that adapt to changing local environments, and alternate their focus of operations on the market and on public tenders, calls into question judgments of failed hybridity based on synchronic analysis.

In conclusion, each of the two experiences compared in this article was deeply conditioned by its context in a variety of ways, with institutional, political, social, economic and cultural factors all playing a role in the configuration of each organizational structure and on its overall performance and perception as a "hybrid organization" or "social enterprise". Our contribution does not suggest that this case-sensitive way of approaching hybridity in organizations is the only or the most accurate method for studying these organizational phenomena. We acknowledge that placing emphasis on the historical and local particularities of the meaning of social enterprising, complicates generalizations or statistical approximations, that are certainly also necessary. Nevertheless, it seems that historical particularism in the study of social enterprises and hybrid organizing is a fairly underrepresented line of research that should be given its own voice and legitimacy.

\section{References}

Battilana, J., and Lee, M. (2014) Advancing Research on Hybrid Organizing - Insights from the Study of Social Enterprises. Academy of Management Annals, 8, 1, pp. 397-441.

Billis, D. (2010) Towards a theory of hybrid organizations. In D. Billis (ed.) Hybrid organizations and the Third Sector: challenges for practices, theory and policy. Basingstoke, Hampshire, UK: Palgrave Macmillan.

Caritas Österreich (2016) Caritas und Du. Wirkungsbericht 2015. Available at: https://www.caritas.at/aktuell/publikationen/wirkungsberichte/.

Dees, J. G. (2012) A Tale of Two Cultures: Charity, Problem Solving, and the Future of Social Entrepreneurship. Journal of Business Ethics, 111, 3, pp. 321-334.

Defourny, J. (2010) Concepts and realities of social enterprise: a European perspective. In A. Fayolle and H. Matlay (eds.), Handbook of Research on Social Entrepreneurship, Edward Elgar Publishing, Cheltenham, UK.

Dey: and Teasdale S. (2016) The tactical mimicry of social enterprise strategies: Acting 'as if' in the everyday life of third sector organizations. Organization, 23, 4, pp. 485-504.

Doherty, B., Haugh, H., and Lyon, F. (2014) Social enterprises as hybrid organizations: A review and research agenda. International Journal of Management Review, 16, 4, pp. 417-436.

DSE-Wien (2014) Sozialintegrative Unternehmen and Beratung in Wien. Wiener Dachverband für sozialökonomische Einrichtungen (DSE-Wien) Available at: www.arbeitplus-wien.at/fileadmin/media/downloads/DSEKataloge/140709-DSE-FOLDER-A4-web_neu.pdf. 
Ebrahim, A., Battilana, J., and Mair, J. (2014) The governance of social enterprises: Mission drift and accountability challenges in hybrid organizations. Research in Organizational Behaviour, 34, pp. 81-100.

Esping-Andersen, G. (2001) Fundamentos sociales de las economías postindustriales. Barcelona: Ariel.

Gidron, B. (2017) The Dual Hybridity of Social Enterprises for Marginalized Populations, Journal of Social Entrepreneurship, 8, 1, pp. 1-13.

Grassl, W. (2011) Hybrid Forms of Business: The Logic of Gift in the Commercial World. Journal of Business Ethics, 100, 1, pp. 109-123.

Hustinx, L. and De Waele, E. (2015) Managing Hybridity in a Changing Welfare Mix: Everyday Practices in an Entrepreneurial Nonprofit in Belgium. Voluntas, 26, pp. 1666-1689.

Jäger. U., and Schröer A. (2014) Integrated Organizational Identity: A Definition of Hybrid Organizations and a Research Agenda. Voluntas, 25, pp. 1281-1306

Kerlin, J. (2009) Social enterprise: a global comparison. University Press of New England, New England.

Kerlin, J. (2010) A Comparative Analysis of the Global Emergence of Social Enterprise. Voluntas, 21, 2, pp. 162-179.

Kerlin, J. (2013) Defining Social Enterprise Across Different Contexts: A Conceptual Framework Based on Institutional Factors. Non-profit and Voluntary Sector Quarterly, 42, 1, pp. 84-108.

Martin, R.L. and Osberg, S. (2007) Social Entrepreneurship: the case for definition. Standford Social Innovation Review, Spring, pp. 29-39.

Mauss, M. [1925]. (2002) The Gift. The form and reason for exchange in archaic societies. Taylor and Francis, London.

Molina, J. L., Valenzuela-García, H., Lubbers M.J., Escribano, P., and Lobato, M. (2017) The Cowl Does Make The Monk. Understanding the emergence of social entrepreneurship in times of downturn. Voluntas, DOI 10.1007/s11266-017-9921-6.

Peattie, K., and Morley, A. (2008) Social enterprises: Diversity and Dynamics, Contexts and Contributions. London: Social Enterprise Coalition.

Powell, W. (1990) Neither market nor hierarchy: Network forms of organization. Research in Organizational Behaviour, 12, pp. 295-336.

Presta, S. (2007) La categoría de don en el marco de la economía social y solidaria. Cuadernos de Antropología Social, 26, pp. 165-182.

Roy, M.J. (2016) Social Enterprises in Scotland. Country report. Unpublished research report. Available soon at http://www.fab-move.eu.

Schneider, H., and Simsa, R. (2016) Social Enterprises in Austria. Country report. Unpublished research report. Available soon at http://www.fab-move.eu.

Schneider, J.W. (1985) Social Problems Theory: The Constructionist View. Annual Review of Sociology, 11, 1, pp. 209229.

Steiner, A., and Teasdale, S. (2016) The playground of the rich? Growing social business in the 21st century. Social Enterprise Journal, 12, 2, pp. 201-216.

Teasdale, S. (2010) Explaining the multifaceted nature of social enterprise: impression management as (social) entrepreneurial behaviour. Voluntary Sector Review, 1, 3, pp. 271-292.

Teasdale, S. (2011) What's in a name? Making sense of social enterprise discourses. Public Policy and Administration, 27, 2, pp. 99-119.

Teasdale, S., Lyon, F., and Baldock, R. (2013) Playing with Numbers: A Methodological Critique of the Social Enterprise Growth Myth. Journal of Social Entrepreneurship, 4, 2, pp. 113-131.

Valenzuela-García, H., Molina, J. L., Lobato, M. M., and Lubbers, M. J. (2015) Empresas sociales en Cataluña ¿Cambio de paradigma o estrategia de clase media? Otra Economía, 9, 17, pp. 177-186. 